\title{
EDITORIAL
}

\section{Barbara Starfield: Passage of the Pathfinder of Primary Care}

\author{
Kurt C. Stange, $M D, P b D$, Editor \\ Ann Fam Med 2011;292-296. doi:10.1370/afm.1293.
}

I learned of Barbara Starfield's sudden death from her husband, Neil "Tony" Holtzman. In his e-mail, sent at 2:43 AM on Saturday, June, 11, 2011, Tony reported that Barbara's absence from a simple act of nurturing, generosity, and generativity was the first sign that something was amiss-she didn't arrive to pick up her neighbor's children from day care.

In the hours after her death, people cried and the ether sighed with stories of simple acts of caring that were the norm for Barbara in her interactions with the world.

Just as she nurtured her 4 children, 8 grandchildren, and her neighbor's children, Barbara Starfield nurtured thousands of people around the world. She did this through her research, her selfless passion, and her guidance of those who care about people and justice and truth. She was a mentor, a champion, a challenger, an innovator, and a scientist. She was an early supporter of the Annals of Family Medicine as a member of our editorial board and an author who was willing to send some of her best work to a then untried new journal, ${ }^{1-7}$ giving it credibility from her mere participation.

A recollection from another editorial board member, Kevin Grumbach, exemplifies her personal impact:

Reading the right book at the right time in one's career can make all the difference. I picked up a copy of Barbara Starfield's book Primary Care: Concept, Evaluation and Policy ${ }^{8}$ soon after it was published in 1992, when I was early in my career as a family physician researcher. Her conceptualization of the basic functions of primary care and her synthesis of the research evidence on the importance of these functions were revelatory to me. The ideas in her book grounded all my future research and policy work in primary care. To this day, when I give presentations on primary care policy, I almost always remind audiences of what I call "Starfield's 4 Cardinal Cs of Primary Care:" first Contact accessibility, Coordination, Comprehensiveness, and Continuity. In this era of dynamic primary care transformation and redesign, Starfield's 4 Cs retain an enduring integrity and relevance what is innovative these days is the means to deliver the core functions of primary care, not the functions themselves.

Soon after reading Barbara's book, I cornered her in the hall at a national meeting where she was keynote speaker and asked for her advice on a study I was conducting measuring the attributes of primary care. She was generous with her time and wisdom, and over the subsequent 20 years I continued to learn from our periodic conversations when we encountered each other at various meetings or served on committees together. She was always passionate about primary care and the importance of primary care in achieving health equity.

Practice-based research network (PBRN) leader Mort Wasserman remembers:

Barbara Starfield was a major force in my professional life. I first met her during my fellowship and was thrilled to encounter her again on the American Academy of Pediatrics task force that led to the creation of its PBRN_-Pediatric Research in Office Settings (PROS). Barbara was a guiding light on that network's steering committee and a principal investigator of a PROS study of referrals from pediatric practice. I sought Barbara's advice many times over the years and regularly refer to her 2 volumes and dozens of papers on primary care research. Her death is a loss to me and it also leaves a gaping hole in primary care studies - one that will only be partly filled by the many people she trained and influenced.

Lew Sandy, Senior Vice President of Clinical Advancement for UnitedHealth Group, notes:

Barbara was a singular voice and tireless advocate for primary care and population health. She held strong opinions, but those opinions were informed by an unusually wide intellectual range. She went out of her way to highlight and advance the work of her many trainees and protégés, and always fought the good fight in pursuit of better health and better health systems.

Family physician Tracy Monk, of British Columbia's Center for Relationship Based Care, recalls:

I remember when I first met her in 2005. She was to be the keynote speaker on the second day of a 2-day health policy conference. I had never been to a health policy conference before. I did not know she was in the room when I stood up 
to comment to a presenter who was laying out a definition of quality in primary care that was all about maximization of targets in chronic disease management guidelines.

I stood up nervously, to say, "You know it's not all about disease in primary care, and if the only thing you measure are diseases, you will miss a great deal of what matters in the lives of patients and in the work of family practice."

I had not read any public policy papers at that point in my life.

I was going purely on my gut sense of what my dayto-day work was as a family doctor. Barbara came up to me afterward to say: "Good for you for saying that. No one ever has the nerve to say it and it is so true." We corresponded ever since and had many lovely e-conversations and walks by watersides in different Canadian cities.

When she was in Vancouver, I loaned her my husband's Lycra cycling shorts and took her on a bike ride along the Vancouver seawall. Maybe a little nervy on both our parts, but we had a ball! Me, a 'lil 'ole family doc from Vancouver, $\mathrm{BC}$, and Barbara, the straight-shooting, no-nonsense high priestess of primary care.

Missing her already....

Barbara's nurturing was balanced with a nature that was not afraid to challenge weak thinking or unwise policy.

Kevin Grumbach continues:

Barbara was as strong willed as she was brilliant. I saw Barbara a couple of weeks before her death, and asked her whether it might be time to add a 5 th " $\mathrm{C}$ " to her conceptual framework, patient-Centered, to capture the contemporary spirit of primary care reforms and the medical home movement. Her response was pure Barbara. "If you provide care that is accessible, comprehensive, coordinated, and with good continuity, then it will be patient-centered."

Elizabeth Bayliss, family physician/researcher and Annals associate editor, recalls her as,

...always thinking out of the box, not afraid to ignore silos, and usually a step ahead of the rest of us. My first encounter with Barbara was when she gave a talk at the 2002 American Academy of Family Physicians Assembly in Denver-on the subject of how we needed to start thinking about managing multimorbidity in primary care. . $3,6,7^{3,7}$

John Frey, another passionate voice for primary care and Annals associate editor,

... didn't know Barbara well but it appeared to me that she had an insight early in her health services research career that systems required a rational clinical core and that her research was driven by a desire to understand both the elements of that core-continuity, trust, breadth of scope of care, clinical decision making-and the way those elements worked their way out in the process of care, the outcomes of care, and the costs of care. She was unrelenting in her search and never rested on having completely understood it but was a true seeker for truth.

For Lillian Gelberg, a family physician whose research addresses vulnerable populations:

Barbara Starfield was a champion for primary care across the globe. Her straightforward message was supported by excellent and clear data, that countries with greater ratios of primary care clinicians had lower morbidity and mortality. She awed us all when she spoke....

Primary care researcher Moira Stewart recalls that,

She was invited along with a dozen other luminaries in 1989 to the first of 5 Foundations of Primary Care Research Conferences. The group of luminaries met for 2 days presenting their ideas and shaping a book called Primary Care Research. She was pivotal and incisive. However, she had a deceiving demeanour because throughout the whole 2 days, she knitted a sweater for one of her children!

Barbara Starfield literally wrote the book on primary care. ${ }^{8,9}$ She generated much of the knowledge $^{5,10-54}$ and methods ${ }^{55-80}$ she so cogently summarized in her books. The fields of pediatrics, family medicine, general practice, and health services and health policy research felt that she was one of theirs. Barbara was beloved not only by the people who knew her personally, but by the unsung heroes of health care around the world who found in Barbara's research and writing a scientific validation of what they rediscovered every day in their work - that relationships based on knowing and caring for the whole person over time matter.

Barbara turned this rigorous research into passionate promotion of what was right. She was an advocate for systems to support primary care relationships that turn fragmentation into integration, isolation into access, and rationing into prioritization and personalization. She used data and reason to advocate for the needs of individuals, families, and communities-for the common good over the all-too-common greed.

This work is not done.

Moira Stewart calls to mind:

The 2008 paper in Healthcare Papers called "Primary Care in Canada: Coming or Going" ${ }^{\prime 11}$ threw down the gauntlet, as only Barbara could, to Canadian citizens, government, and researchers to pull up our socks! At a time when the environment was becoming laissez faire about primary care, permitting erosion of early gains in Canada, she eviscerated our smug contentment and raised a clarion call to re-energize. Her paper has had a massive impact, in no small measure contributing to the momentum leading to Canada's Institutes of Health Research's new strategic initiative on primary health care. My guess is that she has done similar punchy 
analyses in many other countries, thereby improving primary care worldwide.

Ann Louise Kinmonth, Foundation Professor of General Practice at Cambridge University, recalls,

...[a] mid-1990s pair (of studies) showing strong associations first between primary care strength and cost control and secondly between primary care strength and positive health care indicators; those were the days; UK doing best and USA struggling; ah, we give away the dearest things we own as if they were careless trifles....

\section{Kevin Grumbach opines:}

I think one of her greatest satisfactions was seeing so many nations across the globe incorporate her principles of primary care as foundational elements of their national health systems (Barbara advised many of these nations), and one of her greatest exasperations was the failure of her own nation to follow this blueprint for an effective, humane, and equitable health system.

According to Carol Herbert, Professor of Family Medicine and Pathology, and former dean of the Schulich School of Medicine \& Dentistry at the University of Western Ontario:

Barbara was an original thinker, who looked at the evidence and described what she saw: her advocacy for primary care came from her scholarship. She was both principled and pragmatic... Though she knew that the required transformative change to health care would likely not occur in her lifetime, as a scholar she was committed to laying the evidence-based groundwork. She cared passionately about the health of individuals, with names and faces, who make up a population and about equitable health care for those who bear the disproportionate burden of illness. I considered her a role model.

Barbara continued her mentoring, incisive science, and advocacy to the end. Carolyn Clancy, Director of the (US) Agency for Healthcare Research, says:

I have heard from a number of folks who recently (past several weeks) heard from Barbara and reported her energy and passion for primary care and social justice to be at a characteristically high-intense-level. We had recently received an e-mail articulating her concerns regarding an HHS statement on the importance on dramatically improving care for people with multiple chronic illnesses. She has been an inspiration for all of us who care about primary care as an essential component of health care reform. Her departure leaves an enormous legacy-and hole in our hearts.

Tracy Monk, the "lil ole family doc from Vancouver," participated in Barbara's final days of intense energy. In an e-mail sent 4 days before Barbara's death, on the occasion of finishing a revision of a paper that
Barbara coauthored, Tracy quoted the last 10 lines of a poem by Keats ${ }^{82}$ :

I must be near the middle of my story.

O may no wintry season, bare and hoary,

See it half finished: but let Autumn bold,

With universal tinge of sober gold,

Be all about me when I make an end!

And now at once, adventuresome, I send

My herald thought into a wilderness:

There let its trumpet blow, and quickly dress

My uncertain path with green, that I may speed

Easily onward, through flowers and weed.

$$
\text { (Keats, "A Thing of Beauty") }
$$

Although her chapter is now complete, we are still in the middle of the story of Barbara Starfield's life work. It is up us to write the next passage. We must carry on with her labor and her passion to pursue the path toward health, equity, and justice, the beacons that guided Barbara for her 78 years. We owe it to her to pay forward her life's commitment to ask the key questions, demand honest answers, and nurture new talent. As she would remind us, we owe it to our patients, our communities, and the population.

To read or post commentaries in response to this article, see it online at http://www.annfammed.org/cgi/content/full/9/4/292.

Acknowledgment: I am grateful to Tracy Monk and the Annals Editorial Board members and editors who sent e-mail remembrances, and to Bill Phillips, Robin Gotler, Claire Zimmerman, and John Frey for writing and editing help.

\section{References}

1. Starfield B, Lemke KW, Bernhardt T, Foldes SS, Forrest CB, Weiner JP. Comorbidity: implications for the importance of primary care in 'case' management. Ann Fam Med. 2003;1(1):8-14.

2. Starfield B, Lemke KW, Herbert R, Pavlovich WD, Anderson G. Comorbidity and the use of primary care and specialist care in the elderly. Ann Fam Med. 2005;3(3):215-222.

3. Starfield B. Threads and yarns: weaving the tapestry of comorbidity. Ann Fam Med. 2006;4(2):101-103.

4. Forrest CB, Shadmi E, Nutting PA, Starfield B. Specialty referral completion among primary care patients: results from the ASPN Referral Study. Ann Fam Med. 2007;5(4):361-367.

5. Starfield B, Fryer GE Jr. The primary care physician workforce: ethical and policy implications. Ann Fam Med. 2007;5(6):486-491.

6. Valderas JM, Starfield B, Forrest CB, Sibbald B, Roland M. Ambulatory care provided by office-based specialists in the United States. Ann Fam Med. 2009;7(2):104-111.

7. Valderas JM, Starfield B, Sibbald B, Salisbury C, Roland M. Defining comorbidity: implications for understanding health and health services. Ann Fam Med. 2009;7(4):357-363.

8. Starfield B. Primary Care: Concept, Evaluation, and Policy. New York, NY: Oxford University Press; 1992.

9. Starfield B. Primary Care: Balancing Health Needs, Services, and Technology. Rev. ed. New York, NY: Oxford University Press; 1998. 
10. Starfield B, Sharp ES, Mellits ED. Effective care in the ambulatory setting: the nurse's contribution. J Pediatr. 1971;79(3):504-507.

11. Starfield B, Scheff D. Effectiveness of pediatric care: the relationship between processes and outcome. Pediatrics. 1972;49(4):547-552.

12. Starfield B. Health services research: a working model. $N$ Engl J Med. 1973;289(3):132-136.

13. Starfield BH, Simborg DW, Horn SD, Yourtee SA. Continuity and coordination in primary care: their achievement and utility. Med Care. 1976;14(7):625-636

14. Starfield B, Simborg D, Johns C, Horn S. Coordination of care and its relationship to continuity and medical records. Med Care. 1977;15(11):929-938.

15. Starfield B. Patients and populations: necessary links between the two approaches to pediatric research. Pediatr Res. 1981;15(1):1-5.

16. Starfield B. Primary care in the United States. Int J Health Serv. 1986;16(2):179-198.

17. Starfield B. Primary care and health. A cross-national comparison. JAMA. 1991;266(16):2268-2271.

18. Starfield B. Health systems' effects on health status-financing vs the organization of services. Am J Public Health. 1995;85(10):1350-1351.

19. Forrest CB, Starfield B. The effect of first-contact care with primary care clinicians on ambulatory health care expenditures. J Fam Pract. 1996;43(1):40-48

20. Starfield B. Public health and primary care: a framework for proposed linkages. Am J Public Health. 1996;86(10):1365-1369.

21. Starfield B. A framework for primary care research. J Fam Pract. 1996;42(2):181-185

22. Starfield B, Parrino TA. A trial of increased access to primary care. N Engl J Med. 1996;335(12):895-896, author reply 897-898.

23. Starfield B. Outcome of acute myocardial infarction according to the specialty of the admitting physician. N Engl J Med. 1997;336 (22):1607, author reply 1608-1609.

24. Starfield B. The future of primary care in a managed care era. Int J Health Serv. 1997;27(4):687-696.

25. Ferris TG, Saglam D, Stafford RS, et al. Changes in the daily practice of primary care for children. Arch Pediatr Adolesc Med. 1998;152(3):227-233.

26. Forrest CB, Starfield B. Entry into primary care and continuity: the effects of access. Am J Public Health. 1998;88(9):1330-1336.

27. Rajmil L, Starfield B, Plasència A, Segura A. The consequences of universalizing health services: children's use of health services in Catalonia. Int J Health Serv. 1998;28(4):777-791.

28. De Maeseneer J, Hjortdahl P, Starfield B. Fix what's wrong, not what's right, with general practice in Britain. BMJ. 2000;320(7250): 1616-1617.

29. Forrest CB, Tambor E, Riley AW, Ensminger ME, Starfield B. The health profile of incarcerated male youths. Pediatrics. 2000;105 (1 Pt 3):286-291.

30. Starfield B. Deficiencies in US medical care. JAMA. 2000;284(17): 2184-2185.

31. Starfield B. Is US health really the best in the world? JAMA. 2000; 284(4):483-485.

32. Starfield B. Is equity a scientific issue? West J Med. 2000;173(1):7.

33. Braveman P, Starfield B, Geiger HJ. World Health Report 2000: how it removes equity from the agenda for public health monitoring and policy. BMJ. 2001;323(7314):678-681

34. Shi L, Starfield B. The effect of primary care physician supply and income inequality on mortality among blacks and whites in US metropolitan areas. Am J Public Health. 2001;91(8):1246-1250.

35. Starfield B. Medical errors and adverse effects. Br J Gen Pract. 2001; 51(464):232.

36. Forrest CB, Nutting PA, Starfield B, von Schrader S. Family physicians' referral decisions: results from the ASPN referral study. J Fam Pract. 2002;51(3):215-222.
37. Macinko JA, Starfield B. Annotated Bibliography on Equity in Health, 1980-2001. Int J Equity Health. 2002;1(1):1.

38. Shi L, Starfield B, Politzer R, Regan J. Primary care, self-rated health, and reductions in social disparities in health. Health Serv Res. 2002;37(3):529-550

39. Starfield B. Equity in health. J Epidemiol Community Health. 2002; 56(7):483-484.

40. Friedman DJ, Starfield B. Models of population health: their value for uS public health practice, policy, and research. Am J Public Health. 2003;93(3):366-369.

41. Haggerty JL, Reid RJ, Freeman GK, Starfield BH, Adair CE, McKendry R. Continuity of care: a multidisciplinary review. BMJ. 2003. 327(7425):1219-1221.

42. Macinko J, Starfield B, Shi L. The contribution of primary care systems to health outcomes within Organization for Economic Cooperation and Development (OECD) countries, 1970-1998. Health Serv Res. 2003;38(3):831-865.

43. Macinko JA, Shi L, Starfield B, Wulu JT Jr. Income inequality and health: a critical review of the literature. Med Care Res Rev. 2003; 60(4):407-452.

44. Shi L, Macinko J, Starfield B, Wulu J, Regan J, Politzer R. The relationship between primary care, income inequality, and mortality in US States, 1980-1995. J Am Board Fam Pract. 2003;16(5):412-422.

45. Starfield B. William Pickles Lecture. Primary and specialty care interfaces: the imperative of disease continuity. Br J Gen Pract. 2003; 53(494):723-729.

46. Caminal J, Starfield B, Sánchez E, Casanova C, Morales M. The role of primary care in preventing ambulatory care sensitive conditions. Eur J Public Health. 2004;14(3):246-251.

47. Rawaf S, De Maeseneer J, Starfield B. From Alma-Ata to Almaty: a new start for primary health care. Lancet. 2008;372(9647):1365-1367.

48. Scheffler $R$, Bodenheimer $T$, Lombardo $P$, et al. The future of primary care-the community responds. N Engl J Med. 2008;359(25): 2636-2639.

49. Starfield B. The future of primary care: refocusing the system. N Engl J Med. 2008;359(20):2087, 2091.

50. Starfield B. Access, primary care, and the medical home: rights of passage. Med Care. 2008;46(10):1015-1016.

51. Sandy LG, Bodenheimer T, Pawlson LG, Starfield B. The political economy of U.S. primary care. Health Aff (Millwood). 2009;28(4): 1136-1145.

52. Starfield B. Reinventing primary care: lessons from Canada for the United States. Health Aff (Millwood). 2010;29(5):1030-1036.

53. Starfield B. The hidden inequity in health care. Int J Equity Health. 2011;10:15.

54. Starfield B. Challenges to primary care from co- and multi-morbidity. Prim Health Care Res Dev. 2011;12(1):1-2

55. Starfield B. Measurement of outcome: a proposed scheme. Milbank Mem Fund Q Health Soc. 1974;52(1):39-50.

56. Zuckerman ZE, Starfield B, Hochreiter C, Kovasznay B. Validating the content of pediatric outpatient medical records by means of taperecording doctor-patient encounters. Pediatrics. 1975;56(3):407-411.

57. Starfield B. Measuring the uniqueness of primary care. J Ambul Care Manage. 1979;2(3):91-99.

58. Starfield B. Measuring the attainment of primary care. J Med Educ. 1979;54(5):361-369.

59. Starfield B, Steinwachs D, Morris I, Bause G, Siebert S, Westin C. Patient-doctor agreement about problems needing follow-up visit. JAMA. 1979;242(4):344-346.

60. Starfield B, Steinwachs D, Morris I, Bause G, Siebert S, Westin C. Concordance between medical records and observations regarding information on coordination of care. Med Care. 1979;17(7):758-766.

61. Weiner JP, Starfield BH. Measurement of the primary care roles of office-based physicians. Am J Public Health. 1983;73(6):666-671. 
62. Starfield B. Lessons learned from the access survey. Health Aff (Millwood). 1987;6(4):157-159.

63. Starfield B, Weiner J, Mumford L, Steinwachs D. Ambulatory care groups: a categorization of diagnoses for research and management. Health Serv Res. 1991;26(1):53-74.

64. Weiner JP, Starfield BH, Steinwachs DM, Mumford LM. Develop ment and application of a population-oriented measure of ambulatory care case-mix. Med Care. 1991;29(5):452-472.

65. Weiner JP, Starfield BH, Lieberman RN. Johns Hopkins Ambulatory Care Groups (ACGs). A case-mix system for UR, QA and capitation adjustment. HMO Pract. 1992;6(1):13-19.

66. Starfield B. Primary care. J Ambul Care Manage. 1993;16(4):27-37.

67. Starfield B, Simpson L. Primary care as part of US health services reform. JAMA. 1993;269(24):3136-3139.

68. Starfield B. Is primary care essential? Lancet. 1994;344(8930): 1129-1133.

69. Starfield B. Health care reform: the case for a primary care imperative. Health Care Manag. 1994;1(1):23-34.

70. Starfield B. Primary care. Participants or gatekeepers? Diabetes Care. 1994;17(Suppl 1):12-17.

71. Starfield B, Powe NR, Weiner JR, et al. Costs vs quality in different types of primary care settings. JAMA. 1994;272(24):1903-1908.

72. Vivier PM, Bernier JA, Starfield B. Current approaches to measuring health outcomes in pediatric research. Curr Opin Pediatr. 1994; 6(5):530-537.
73. Starfield B, Weiner J. Capitation adjustment for pediatric populations. Pediatrics. 1997;99(4):651.

74. Riley AW, Forrest CB, Starfield B, Green B, Kang M, Ensminger M. Reliability and validity of the adolescent health profile-types. Med Care. 1998;36(8):1237-1248

75. Riley AW, Green BF, Forrest CB, Starfield B, Kang M, Ensminger ME. A taxonomy of adolescent health: development of the adolescent health profile-types. Med Care. 1998;36(8):1228-1236.

76. Starfield B. The Medical Home Index applies primarily to children with special health care needs. Ambul Pediatr. 2004;4(2):192, author reply 192-193.

77. Starfield B, Shi L. The medical home, access to care, and insurance: a review of evidence. Pediatrics. 2004;113(5)(Suppl):1493-1498.

78. Shi L, Macinko J, Starfield B, Politzer R, Wulu J, Xu J. Primary care, social inequalities, and all-cause, heart disease, and cancer mortality in US counties, 1990. Am J Public Health. 2005;95(4):674-680.

79. Starfield B. Insurance and the U.S. health care system. $N$ Engl J Med. 2005;353(4):418-419.

80. Starfield B, Shi L, Macinko J. Contribution of primary care to health systems and health. Milbank Q. 2005;83(3):457-502.

81. Starfield B. Primary care in Canada: coming or going? Healthc Pap. 2008;8(2):58-62.

82. Keats, John. A thing of beauty. In: Poetical Works. London: Macmillan; 1884. New York: Bartleby.com; 1999.

\section{EDITORIAL}

\section{The Potential of Sensor-Based Monitoring as a Tool for Health Care, Health Promo- tion, and Research}

Kevin G. Stanley, PbD

Nathaniel D. Osgood, PbD

Departments of Computer Science and of Community Health \& Epidemiology, University of Saskatchewan, Saskatoon, Saskatchewan, Canada

Ann Fam Med 2011;296-298. doi:10.1370/afm.1292.

Conflicts of interest: authors report none

\section{CORRESPONDING AUTHOR}

Nathaniel D. Osgood, PhD

Department of Computer Science

School of Public Health

176 Thorvaldson Bldg

University of Saskatchewan

110 Science Pl

Saskatoon, S7N 5C9

Saskatchewan, Canada

osgood@cs.usask.ca
$\mathrm{T}$

his issue of the Annals features an article on the automated observation of a small number of residents in a care facility. ${ }^{1}$ Berke and colleagues use portable devices outfitted with tiny sensors to infer the activity level and social context of the study participants. Perhaps more importantly, the authors validate the sensor-based analysis using traditional instruments, showing that the sensor-based approach provides equivalent diagnostic utility while reducing error and reporting load on participants and increasing the temporal fidelity and richness of the data. As one of the first forays of ubiquitous sensing into the field 